\title{
About retardation of a physicochemical processes in overpressured sediments, South-Caspian basin, Azerbaijan
}

\author{
Akper Feyzullayev \\ Geology Institute of the Azerbaijan National Academy of Sciences, Baku, Azerbaijan; fakper@gmail.com
}

Received 29 September 2010; revised 15 October 2010; accepted 22 October 2010.

\begin{abstract}
In paper the role of excess pressures in catagenic processes of the South-Caspian basin (SCB) is considered. The results of the carried out researches taking into account world experience on the given problem allow to conclude, that SCB (mainly its deep-water part), as well as a number of other basins of the world with overpressures, is characterized by retardation of processes cracking of kerogen and oil, and also reaction of transformation of clay minerals. Periodic intensification of these processes can provoke development of diapirs and mud volcanoes, which are the centers of pulse unloading of a hydrocarbon products from system. The conclusion about high prospects of revealing of hydrocarbon accumulations in deep buried deposits in overpressured basins is made.
\end{abstract}

Keywords: Overpressures; Cracking; Kerogen; Oil; Smectite; Illite; Retardation; South Caspian Basin

\section{INTRODUCTION}

The conventional sedimentary theory of formation of oil and gas from organic material has two key process controlling factors: temperature and duration time for the initial organic matter (OM) [1-4].

Often the role of pressure in generation of hydrocarbons (HCs) is taken to be insignificant $[2,5,6]$. However, theoretical and experimental investigations of the last few years dispute this statement. Thick impermeable clay deposits represent an almost closed system [7-9] where the processes of thermal maturation of $\mathrm{OM}$, generation of hydrocarbons (HCs) and, especially, cracking of oil to gas, produce abnormally high fluid pressure (overpressure) [9-14].
In a closed system because of the absence of conditions for $\mathrm{HC}$ outflow and removal from the system there will be a continuous increase of volume as kerogen (density around $2 \mathrm{~g} / \mathrm{cm}^{3}$ ) converts to hydrocarbons (density less than $1 \mathrm{~g} / \mathrm{cm}^{3}$ ), thus promoting the growth of pore pressures in the system, which can reach and even exceed lithostatic pressure [10,12]. As known from physical chemistry, the absence of a capability of outflow from a closed system of products results in retardation of the reaction rates as has been noted on the basis of experimental investigations and comparative analysis of the processes in worldwide basins [7-9,15-19]. The retardation of OM maturation in overpressure conditions is also associated with abnormally low values of vitrinite reflectance (Ro\%) and $\mathrm{T}_{\max }$ in rock pyrolysis [7,19-21].

The termination of clay mineral transformations at overpressured depth intervals (e.g. constancy of the smectite content vs. depth) has also been established [22].

\section{RESULTS OF STUDIES}

The South Caspian Basin (SCB) is one of the most striking examples where, due to the geological history and recent geological structures, very favorable conditions exist for the formation of overpressure. In the Pliocene-Quaternary avalanche sedimentation (up to $3 \mathrm{~km} / \mathrm{myr}$ ) has been inferred. The total sediment thickness (up to $25 \mathrm{~km}$ ) obtains from Jurassic time onwards. In the Cenozoic section plastic terrigenous rocks prevail. Moreover, the SCB is characterized by an abnormally low tem- perature gradient, in the central deepest part of the basin the temperature gradients vary between 15 $18^{\circ} \mathrm{C} / \mathrm{km}$. As a result, overpressures are observed.

The analysis of pressure data and their gradients in the SCB, based on well logs and actual measures of pressures in wells up to depth of about $7 \mathrm{~km}$, showed the spatial variability. The intensity increases in a southsouthwest direction, coinciding precisely with changes in the clay content in the formations and the thickness of the clay series [23] (Table 1). 
Figure 1 shows that the highest overpressures are to be found within the limits of the Baku archipelago (zone III), where the average pressure gradient is $18 \mathrm{MPa} / \mathrm{km}$ (see Table 1).

Table 1 and Figure 1 reflect pressures in the Productive series (PS - lower Pliocene), a main petroleum reservoir in the SCB. Underlying the PS, Oligocene-Mione deposits were drilled in the elevated flanks of the SCB on some fields. In the central part of the basin these deposits lie very deep and information about their thermodynamic conditions is not available. However, taking into account that the formations relate to the source rocks [22,24-28], one expects even more contrast in excess pressures than in the reservoir, reaching and even exceeding lithostatic (geostatic) pressure. Confirmation to this point is the widespread development in the SCB of diapirism and mud volcanism.

On the basis of the non-uniform spatial distribution of fluid pressures, there are unequal conditions for thermal transformation of OM. In the central deep-water part of SCB (zone III on Figure 1) one anticipates the least maturity for the thermal transformation of OM because:

1) Mello and Karner [29] indicate that deposits with overpressure are characterized by a low thermal conductivity and play a role of insulators for heat flow. The deep-water part of the SCB, with the largest overpressure (Figure 2), is distinguished by the lowest temperature gradients (Figure 3).

2) The thickness of Oligocene-Miocene source rocks, present mainly in clay lithofacies (up to $80-90 \%$ of a section) in the deep-water part of the SCB, is largest and exceeds $3000 \mathrm{~m}$. The HC output formed there, both as a result of transformation of $\mathrm{OM}$ and of cracking of oil into gas, will be characteristic of a more closed system in comparison to the elevated part of the basin. Accordingly, lower thermochemical reactions rates of $\mathrm{OM}$ transformation are to be expected in source rocks in the $\mathrm{SCB}$, related to the development of overpressure.

For verification pyrolysis parameters and measured values of reservoir rocks (Lower Pliocene) and source rocks (Miocene) (Table 2) were compared.

As Table 2 shows, although the Miocene deposits lie deeper than the overlying, younger Lower Pliocene formations they are, nevertheless, characterized by lower pyrolysis values parameters (PI, $\mathrm{T}_{\max }$ and Ro), reflecting the lower degree of OM maturation.

The change with depth of values of Ro in the SCB is also of interest. According to Figure 4, two trends of this parameter with depth are clearly observed. The trend with a higher Ro gradient is characteristic for the onshore fields on the elevated flank part of the SCB, while the trend with a low Ro gradient is more characteristic

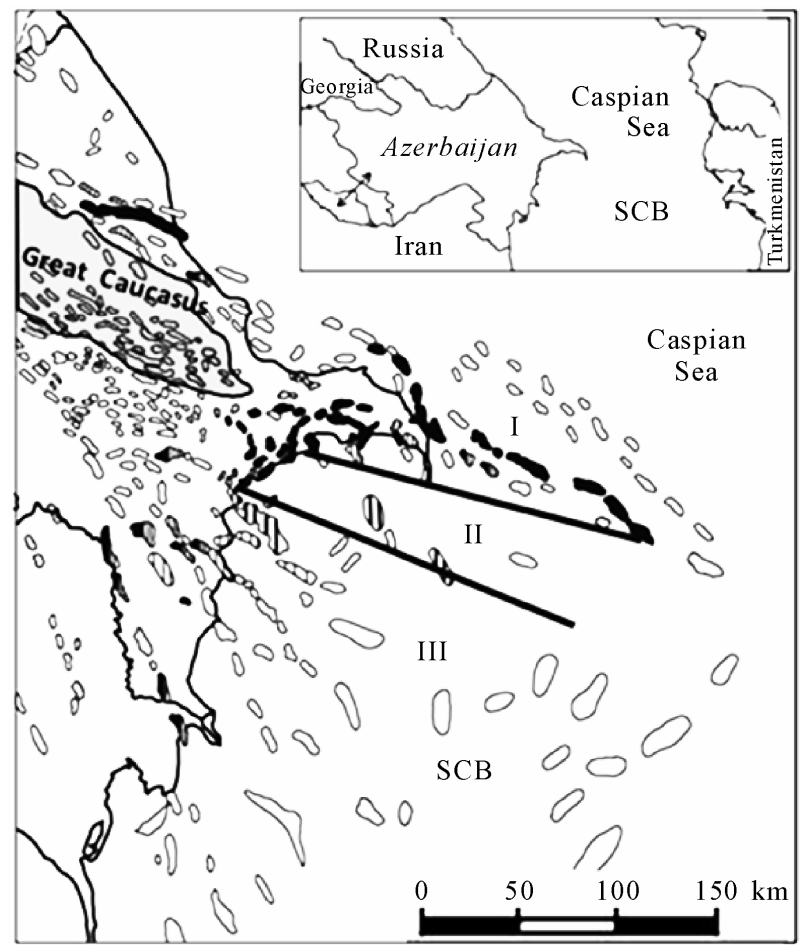

Figure 1. Formation pressure distribution zones in the SCB: I - Absheron p-la and Absheron archipelago; II - South Absheron water area; III - Baku archipelago.

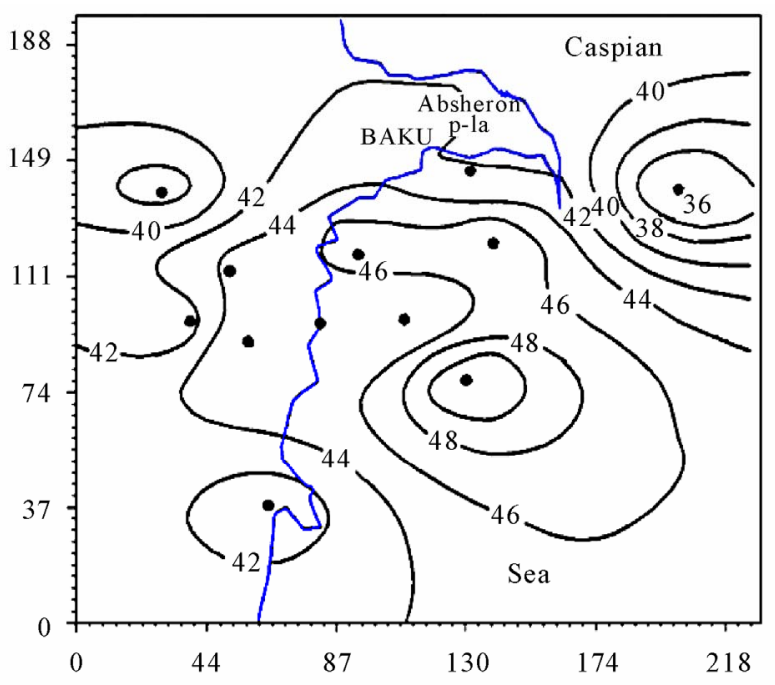

Figure 2. Distribution of excess pressures (MPa) (relative to hydrostatic pressure) in the SCB at a depth of $6 \mathrm{~km}$ [30]. Blue line is coastline.

for offshore fields distinguished by overpressure.

Note that the zone with overpressure (Baku archipelago) differs from the zone with rather moderate fluid pressure (Absheron archipelago) as also indicated by carbon isotope composition of oils (Figure 5). 
Table 1. Thicknesses of clayey series and associated pressure gradients in the SCB [23].

\begin{tabular}{|c|c|c|c|c|c|}
\hline \multirow{2}{*}{ Zones } & \multicolumn{4}{|c|}{$\begin{array}{l}\text { Average values of a clay rocks thickness }(m) \text { for } \\
\text { different depth intervals }\end{array}$} & \multirow{2}{*}{$\begin{array}{l}\text { Average values of pressure } \\
\text { gradients, } \mathrm{MPa} / \mathrm{km}\end{array}$} \\
\hline & $1-2 \mathrm{~km}$ & $2-3 \mathrm{~km}$ & $3-4 \mathrm{~km}$ & $4-5 \mathrm{~km}$ & \\
\hline I-Absheron p-la and Absheron archipelago & 50 & 40 & 30 & 20 & 13.5 \\
\hline II-South Absheron water area & 750 & 235 & 185 & 150 & 16.3 \\
\hline III-Baku archipelago & 900 & 725 & 460 & 350 & 18.0 \\
\hline
\end{tabular}

Table 2. Comparison parameters of pyrolysis and values of $\mathrm{R}_{\mathrm{o}}(\%)$ for a reservoir and source rocks in SCB.

\begin{tabular}{ccccc}
\hline \multirow{2}{*}{ Age of rocks } & Depth interval, $\mathbf{m}$ & \multicolumn{2}{c}{ Pyrolysis parameters } & \multirow{2}{*}{$\mathbf{R}_{\mathbf{0}}, \boldsymbol{\%}$} \\
\cline { 3 - 4 } & & $\mathbf{P I}=\mathbf{S}_{\mathbf{1}} /\left(\mathbf{S}_{\mathbf{1}}+\mathbf{S}_{\mathbf{2}}\right)$ & $\mathbf{T}_{\text {max }},{ }^{\circ} \mathbf{C}$ & $0.46-0.82 / \mathbf{0 . 6 6}$ \\
Lower Pliocene (reservoir) & $1230-5688$ & $0.23-0.96 / \mathbf{0 . 5 2}$ & $417-472 / \mathbf{4 3 1}$ & $0.38-0.48 / \mathbf{0 . 4 4}$ \\
\hline Miocene (source rocks) & $4295-5775$ & $0.03-0.39 / \mathbf{0 . 1 3}$ & $419-439 / \mathbf{4 2 9}$ & \\
\hline
\end{tabular}

*limits/average.

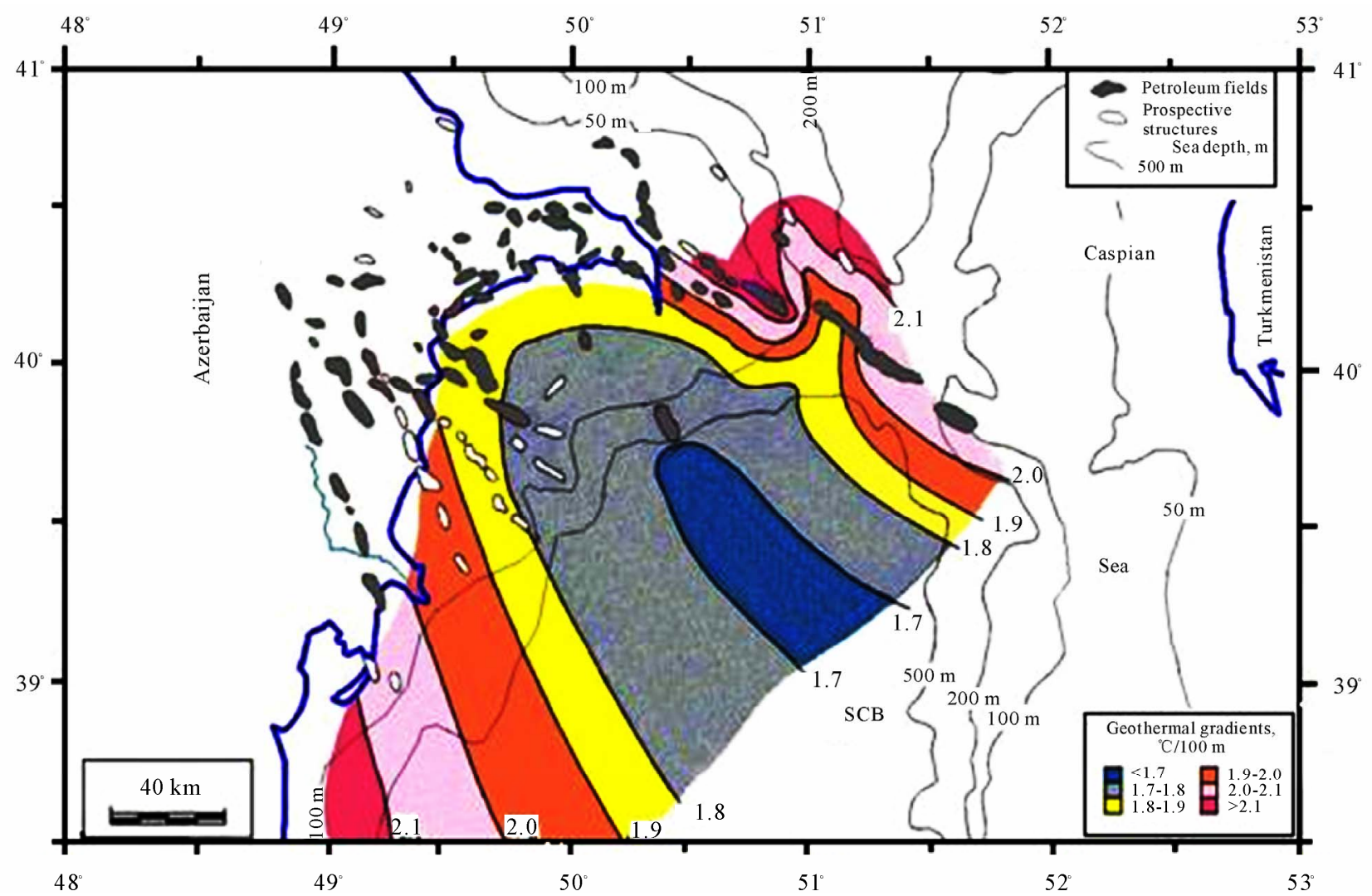

Figure 3. Distribution of temperature gradient $\left({ }^{\circ} \mathrm{C} / 100 \mathrm{~m}\right)$ in the SCB.

In the greater part of the SCB the clayey rocks consist mineralogically mainly of smectite $(40 \%-50 \%$ and even higher) [23].

The onset temperature for smektite dehydration depends on the geological conditions of the basin and can vary within the limits of $75^{\circ} \mathrm{C}-150^{\circ} \mathrm{C}$ [31]. The critical temperature for diagenetic transformation of smectite varies within the limits of $86^{\circ} \mathrm{C}-110^{\circ} \mathrm{C}$ [32].

Because the SCB has an abnormally low non-stationary temperature regime, the process of intensive dehydration of clays (transformation of smectite to illite) is expected to take place here at depths greater than $7 \mathrm{~km}$. 


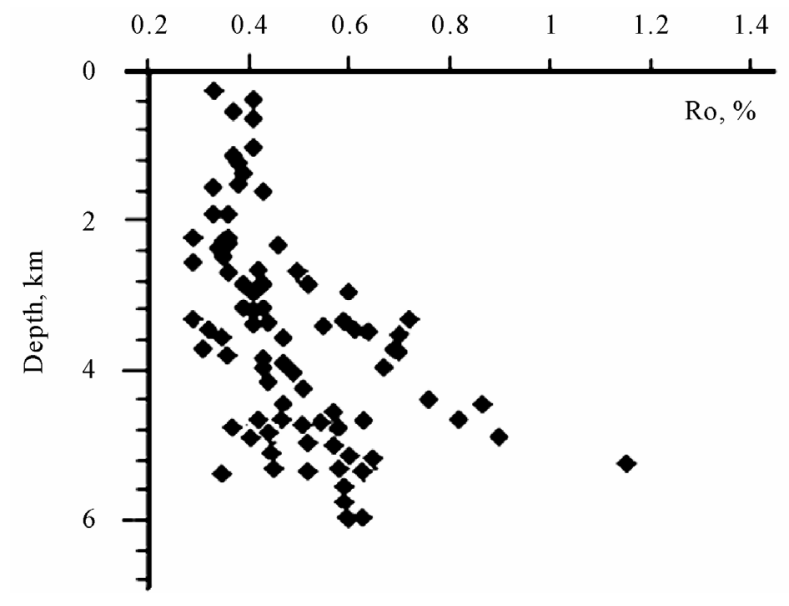

Figure 4. Vitrinite reflectance $\left(\mathrm{R}_{\mathrm{o}}, \%\right)$ vs. depth in the SCB.

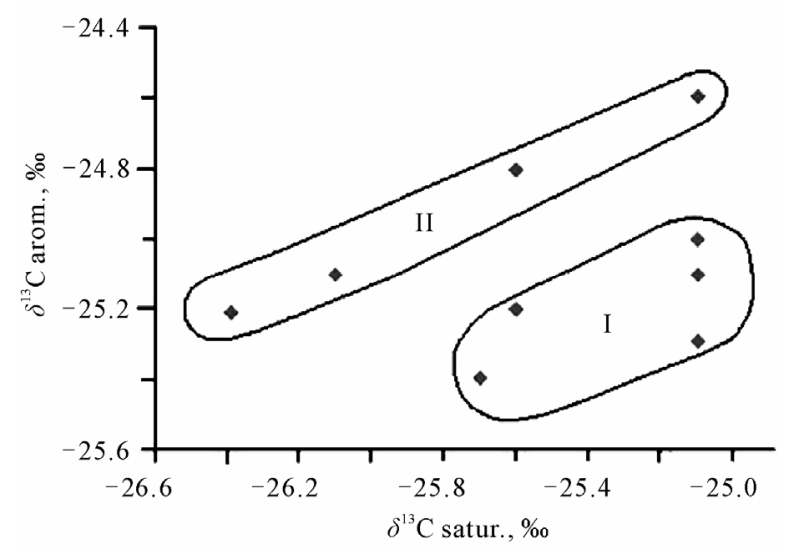

Figure 5. Iisotope composition of carbon in saturated and aromatic fractions of oils in the SCB: oil fields with normal pressures (I) and overpressures (II).

However, the average value of the smectite percentage does not change essentially in an interval of depths up to $6.2 \mathrm{~km}$ for both the Absheron and Baku archipelagoes [33].

The comparison of change of the smectite content within Absheron and Baku archipelagoes indicates a relatively higher content of smectite in the Baku archipelago in comparison with the Absheron archipelago (Figure 6).

Because the Baku archipelago, in comparison with Absheron water area (see Table 1), is characterized by higher pore pressure gradients, the preservation of smectite in the Baku archipelago is caused by retardation of smectite to illite transformation under overpressure conditions.

The rate of thermochemical reactions in sediments with overpressures can increase sharply if, by virtue of any factor (tectonic, thermal and chemical convection, effect of gravitational emersion of fluidized viscousunstable clay mass, etc.) and the formed products are

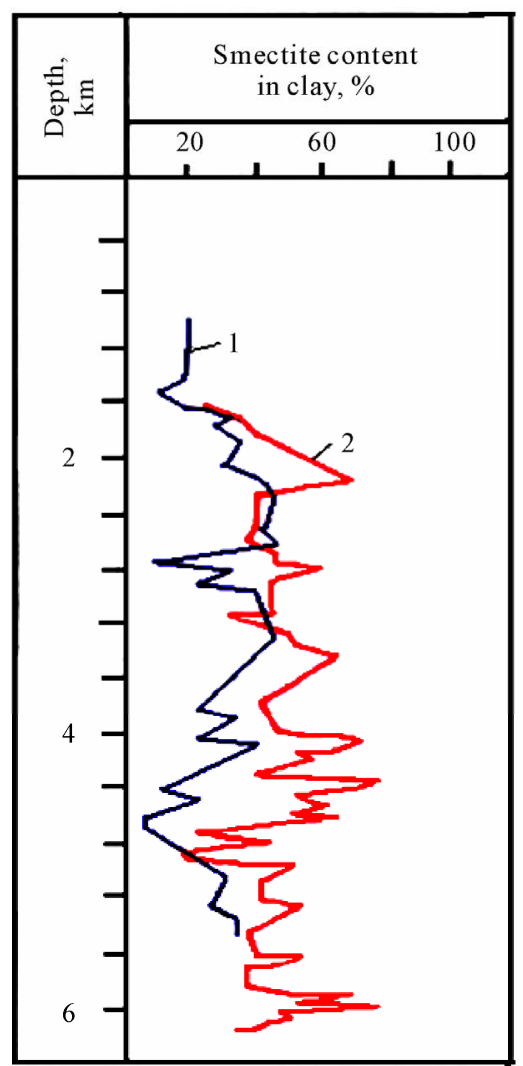

Figure 6. Percentage of smectite in shales vs. depth in the SCB: 1-Absheron Archipelago; 2-Baku Archipelago.

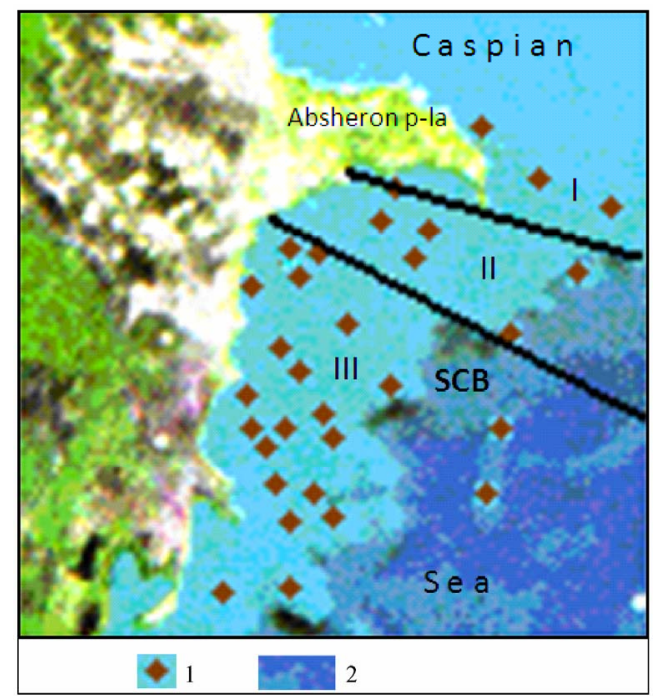

Figure 7. The mud volcanoes location in the Caspian Sea (Azerbaijan sector): I, II and III - zone with, accordingly, normal, moderate and abnormal high pressures; 1-mud volcanoes; 2-deep water part of sea.

removed from the system (for example, during eruptions of mud volcanoes or formation of mud diapirs). This 
statement is confirmed by spatial change of the development density of mud volcanoes. The more density of their development is noted in overpressured zone (zone III) in comparison with the zones of moderate and normal pressures (zone I and II, accordingly) (Figure 7).

The migration of HCs will then have an explosive character, which can also be promoted by earthquakes occurring in the SCB, the hypocenters of which are mostly at shallow depths [25].

\section{CONCLUSIONS}

The results of investigations indicate that the SCB is characterized by the following features:

- unequal conditions of generations and expulsion of HCs from source rocks;

- the processes of HCs generation (mainly in deep-buried part of SCB) are shifted to relatively deeper depths, from where the expulsion of HCs from source rocks is complicated. As a result in this zone, characterizing as a relatively closed system, overpressures and mud volcanoes are widely developed;

- there is retardation of thermal transformation of $\mathrm{OM}$ and clay minerals, generation of oil and cracking it into gas in overpressured source rocks;

- mud volcanoes are focal centers of periodic explosive unloading of HCs from overpressured source rocks.

Results of investigations have both scientific and applied significance.

The scientific significance is that the classical scheme of the vertical zonality of HC generation [2,3] should be improved with reference to the overpressured basins. According to the latest discoveries of large accumulations of oil at depths of $8.5-10.5 \mathrm{~km}$ in the Gulf of Mexico [34], the "oil window" in basins with overpressure where the retardation of OM transformation is observed, have to be shifted in the classical scheme of the vertical zonality of $\mathrm{HC}$ generation to greater depths in comparison with the basins without overpressure.

This indicates an increase in liquid $\mathrm{HC}$ resources for the deep-water parts of basins like the South Caspian, which in turn challenges the necessity to increase explorations in overpressured zones.

\section{REFERENCES}

[1] Lopatin, N.V. (1971) Temperature and time as factors of coalification. Izvestiya Akademii Nauk SSSR, Seriya gelogicheskaya (in Russian), 3, 95-106.

[2] Tissot, B.P. and Welte, D.H. (1984) Petroleum formation and occurrence. Springer-Verlag, Berlin.

[3] Vassoevich, N.B. (1974) Principal scheme of a vertical zoning and oil and gas generation. Proceedings of the
Academy of Sciences of USSR. Geological Series (in Russian), 5, 17-29.

[4] Waples, D.W. (1980) Time and temperature in petroleum formation: Application of Lopatin's method to petroleum exploration. AAPG Bulletin, 64, 916-926.

[5] Allen, E.B. and Allen, M.F. (1990) The mediation of competition by mycorrhizae in successional and patchy environments. In: Grace, J.B. and Tilman, D. Eds., Perspectives on Plant Competition, Academic Press, Cambridge, 367-389.

[6] Khorasani, G.K. and Michelsen, J.K. (1994) Four-dimensional fluorescence imaging of oil generation: Development of a new fluorescence imaging technique. Organic Geochemistry, 22, 211-223. doi:10.1016/0146-6380(95)90018-7

[7] Hao, F., Li, S., Sun, Y. and Zhang, Q. (1996) Organic matter maturation and petroleum generation model in the Yinggehai and Qiongdongnan basins. Science in China. Series D, 39, 650-658

[8] Helgeson, H.C. (1985) Adjective-diffusive/dispersive transport of chemically reacting species in hydrothermal system. Grant US Department of Energy: DE-FG03-85ER13419.

[9] Osborne, M.J. and Swarbrick, R.E. (1997) Mechanisms for generating overpressure in sedimentary basins: A reevaluation. AAPG Bulletin, 81, 1023-1041.

[10] Barker, C. (1990) Calculated volume and pressure changes during the thermal cracking of oil to gas in reservoirs. AAPG Bulletin, 74, 1254-1261.

[11] Duppenbecker, S.J., Riley, G.W., Abdullayev, N.R., Green, T.J. and Doran, H. (2009) Petroleum systems dynamics of the south caspian basin. AAPG Hedberg Research Conference, Napa, 3-7 May 2009, 13.

[12] Luo, X. and Vasseur, G. (1996) Geopressuring mechanism of organic matter cracking: numerical modeling. AAPG Bulletin, 80, 856-874.

[13] Momper, J.A. (1980) Generation of abnormal pressure through organic matter transformation. AAPG Bulletin, 64,753-761.

[14] Xie, X., Bethke, C.M., Lii, S., Liu, X. and Zheng, H. (2001) Overpressure and petroleum generation and accumulation in the Dongying Depression of the Bohaiwan Basin, China. Geofluids, 1, 257-271. doi:10.1046/j.1468-8123.2001.00017.x

[15] Hao, F., Zou, H., Gong, Z., Yang, S. and Zeng, Z. (2007) Hierarchies of overpressure retardation of organic matter maturation: Case studies from petroleum basins in China. AAPG Bulletin, 91, 1467-1498. doi:10.1306/05210705161

[16] He, S., Middleton, M., Kaiko, A., Jiang, C. and Li, M. (2002) Two case studies of thermal maturity and thermal modelling within the overpressured Jurassic rocks of the Barrow Sub-basin, north west shelf of Australia. Marine and Petroleum Geology, 19, 143-159. doi:10.1016/S0264-8172(02)00006-5

[17] Huijun, L., Tairan, W., Zongjin, M. and Wencai, Z. (2004) Pressure retardation of organic maturation in clastic reservoirs: A case study from the Banqiao Sag, Eastern China. Marine and Petroleum Geology, 21, 1083-1093. doi:10.1016/j.marpetgeo.2004.07.005

[18] Wang, C.Y. and Du, J.G. (2007) Experimental study on existence of hydrocarbon under high pressure and tem- 
perature in deep lithosphere. The 23rd International Meeting on Organic Geochemistry, Torquay, 9-14 September 2007, 144.

[19] Zou, Y.-R. and Peng, P. (2001) Overpressure retardation of organic-matter maturation: a kinetic model and its application. Marine and Petroleum Geology, 18, 707-713. doi:10.1016/S0264-8172(01)00026-5

[20] McTavish, R.A. (1998) The role of overpressure in the retardation of organic matter maturation. Journal of Petroleum Geology, 21, 153-186. doi:10.1111/j.1747-5457.1998.tb00652.x

[21] Vandenbroucke, M., Durand, B. and Oudin, J.L. (1983) Detecting migration phenomena in a geological series by means of $\mathrm{C}_{1}-\mathrm{C}_{35}$ hydrocarbon amounts and distributions. In: Bjoroy, M., et al. Ed., Advances in Organic Geochemistry, Pergamon Press, Oxford, 147-155.

[22] Dódony, I. and Lovas, G.A. (2003) Crystalchemistry of clay minerals around the border of an overpressure zone in one of the deep sub-basins of the southern part of the great Hungarian plain. Acta Mineralogica-Petrographica, Abstract Series, 1, 26.

[23] Buryakovsky, L.A., Dzhevanshir, R.D. and Aliyarov, R.Y. (1986) Geophysical methods of studying geofluid pressures(in Russian). Elm, Baku.

[24] Abrams, M.A. and Narimanov, A.A. (1997) Geochemical evaluation of hydrocarbons and their potential sources in the western South Caspian depression, Republic of Azerbaijan. Marine and Petroleum Geology, 14, 451-468. doi:10.1016/S0264-8172(97)00011-1

[25] Feyzullayev, A.A., Tagiyev, M.F. and Lerche, I. (2008) Tectonic control on fluid dynamics and efficiency of gas surveys in different tectonic settings. Energy Exploration and Exploitation, 26, 363-374. doi: $10.1260 / 014459808788262260$

[26] Guliyev, I.S. and Feyzullayev, A.A. (1996) Geochemistry of hydrocarbon seepages in Azerbaijan. Hydrocarbon migration and its near-surface expression. AAPG Memoir, 66, 63-70.

[27] Gurgey, K. (2003) Correlation, alteration, and origin of hydrocarbons in the GCA, Bahar, and Gum Adasi fields, western South Caspian Basin: Geochemical and multivariate statistical assessments. Marine and Petroleum Geology, 20, 1119-1139. doi:10.1016/j.marpetgeo.2003.10.002

[28] Katz, K.J., Richards, D., Long, D. and Lawrence, W. (2000) A new look at the components of the petroleum system of the South Caspian Basin. Journal of Petroleum Science and Engineering, 28, 161-182. doi:10.1016/S0920-4105(00)00076-0

[29] Mello, U.T. and Karner, G.D. (1996) Development of sediment overpressuring and its effect on thermal maturation: Application to the Gulf of Mexico basin. $A A P G$ Bulletin, 80, 1367-1396.

[30] Tagiyev, M.F., Nadirov, R.S., Bagirov, E.B. and Lerche, I. (1996) Oil and gas petroleum systems in rapidly subsiding basins. AAPG/ASPG Research Symposium, Baku, 6-9 October 1996.

[31] Bruce, C.H. (1984) Smectite dehydration its relationship to structural development and hydrocarbon accumulation in the northern Gulf of Mexico basin. AAPG Bulletin, 68, 673-683.

[32] Fertl, W.H. (1976) Abnormal formation pressures. Elsevier, Amsterdam.

[33] Kheirov, M.B. (1979) The effect of sediment deposition depth on the transformation of shale minerals. Transactions of the Academy of Sciences of the Azerbaijan Soviet Socialist Republic. Geoscience Series (in Russian), 8, 144-151.

[34] Arnott, S. (2009) BP discovers "giant" oil field deep beneath waters of the Mexican Gulf. The Independent (Newspaper), 3 September 2009. 